\title{
Role of Bifidobacterium bifidum and plant food extracts in improving microflora and biochemical and cytogenetic parameters in adjuvant arthritis
}

\author{
By S.Y. Al-Okbi, ${ }^{1}$ D.A. Mohamed, ${ }^{1 *}$ S.M. Donya ${ }^{2}$ and A.B. Abd El Khalek ${ }^{3}$
}

\author{
${ }^{1}$ Food Sciences and Nutrition Department, National Research Centre, Cairo, Egypt. \\ ${ }^{2}$ Cytogenetic Department and ${ }^{3}$ Dairy Department, National Research Centre, Cairo, Egypt. \\ ( ${ }^{\star}$ Corresponding author: dohamohamed@yahoo.com)
}

\section{RESUMEN}

Papel de Bifidobacterium bifidum y extractos de alimentos vegetales en la mejora de la microflora y en parámetros bioquímicos y citogenéticos en la artritis adyuvante.

El objetivo de la presente investigación fue encontrar extractos de alimentos vegetales y probióticos que puedan tener bioactividad hacía la inflamación crónica. Mezclas de tres extractos de alimentos vegetales conocidos por su riqueza en compuestos fenólicos, carotenoides y tocoferoles han sido preparadas. La actividad anti-inflamatoria de las diferentes mezclas y de bacterias probióticas (Bifidobacterium bifidum) fue evaluada en artritis adyuvante en ratas. El efecto anti-inflamatorio, mecanismo de acción y salubridad de las tres mezclas y de Bifidobacterium bifidum ha sido estudiado mediante la medida del tamaño de la inflamación y la determinación de biomarcadores de inflamación y estrés oxidativo, del perfil de bacterias del colón y de parámetros citogenéticos específicos. El contenido de tocoferoles, $\beta$-caroteno y compuestos fenólicos en las mezclas fue determinado. Los resultados muestran que las mezclas y los Bifidobacterium bifidum poseen un prometedor efecto anti-inflamatorio. El mecanismo de acción parece involucrar una reducción de los biomarcadores inflamatorios y del estrés oxidativo y tiene un efecto sobre la microflora del colón. La fragmentación del DNA y la genotoxicidad inducida por la artritis adjuvante fue prevenida con la suplementación de las mezclas ensayadas.

PALABRAS CLAVE: Artritis adjuvante - Bifidobacterium bifidum - Cambios bioquímicos - Extractos de plantas - Microflora - Parámetros citogenéticos.

\section{SUMMARY}

Role of Bifidobacterium bifidum and plant food extracts in improving microflora and biochemical and cytogenetic parameters in adjuvant arthritis.

The aim of the present research was to discover plant food extracts and probiotics that may have bioactivity towards chronic inflammation. Three plant food extract mixtures expected to be rich in phenolic compounds, carotenoids and tocopherols were prepared. The anti-inflammatory activity of the different mixtures as well as probiotic bacteria (Bifidobacterium bifidum) were evaluated in adjuvant arthritis in rats. The anti-inflammatory effect, mechanism of action and safety of the three mixtures and Bifidobacterium bifidum were studied by measuring the size of inflammation and the determination of inflammatory and oxidative stress biomarkers, colonic bacteria profile and specific cytogenetic parameters. The contents of tocopherols, $\beta$-carotene and phenolic compounds in the mixtures were determined. The results show that the tested mixtures and Bifidobacterium bifidum possess promising anti-inflammatory effects. The mechanism of action seems to involve a reduction in oxidative stress and inflammatory biomarkers and an effect on colonic microflora. Genotoxicity and DNA fragmentation induced by adjuvant arthritis were prevented after supplementation with the tested mixtures.

KEY-WORDS: Adjuvant arthritis - Bifidobacterium bifidum - Biochemical change - Cytogenetic parameters Microflora - Plant extracts.

\section{INTRODUCTION}

Food is rich in biological active constituents, nutraceuticals, which may have beneficial effects on chronic diseases, among which are carotenoids, tocopherols and phenolic compounds which have been previously reported to have health benefits such as antioxidant and anti-inflammatory activity (Ansari et al., 2006; Prakash et al., 2007; Arranz et al., 2008). The disease studied in the present research was chronic inflammatory disease represented by the adjuvant arthritis model in rats which is similar to rheumatoid arthritis in humans. Such a disease involves high oxidative stress and inflammation (lalenti et al., 1993). There is extensive evidence for the critical role of the reactive oxygen species (ROS) and nitric oxide (NO) produced by phagocytes in the development of the inflammatory processes and pathogenesis of autoimmune diseases including rheumatoid arthritis. It is worthy to mention that DNA damage was reported in arthritic rats (Mythilypriya et al., 2008). Antioxidants are emerging as prophylactic and therapeutic agents which scavenge free radicals and prevent DNA damage (Ratnam et al., 2006).

Tomatoes, carrots and sweet potatoes are rich in carotenoids. Broccoli, green tea and rosemary herb were reported as good sources of phenolic compounds. Hazelnuts, walnuts and wheat germ are among the plant food sources that are rich in tocopherols. Vitamin E (alpha-, beta-, gamma- and 
delta-tocopherol and alpha-, beta-, gamma- and delta-tocotrienol) is a powerful antioxidant which is essential for human health. Gamma tocopherol has been recently reported to possess potent antiinflammatory and antioxidant properties (Dietrich et al., 2006). Carotenoids are known to have antioxidant activity. Moreover, the consumption of foods rich in phenolic compounds reduces the incidence of inflammation and modifies the biomarkers of oxidative stress (Garg et al., 2007). Dietary polyphenols were reported to be promising chemopreventive agents in humans because they modify the gene expression reponsible for certain antioxidant enzymes (Kluth et al., 2007). However, the potential hazards of polyphenol consumption which were evaluated primarily in experimental studies showed that polyphenols may have genotoxic effects in high doses (Mennen et al., 2005). Some probiotic bacteria have shown to possess potential benefits in chronic inflammatory diseases (Marteau et al., 2001).

The objective of the present research is to prepare and evaluate mixtures of plant food extracts, nutraceuticals, for protection from the occurrence of chronic inflammatory disease. The synergistic antioxidant and anti-inflammatory effects of collective plant food extracts were assessed through the determination of specific biomarkers and colonic microflora and by evaluating their anti-mutagenic potency through different cytogenetic parameters in an adjuvant arthritis model in rats. These extracts were selected due to their high contents of phenolic compounds, tocopherols and carotenoids, which are expected to have antioxidant and free radical scavenging capacity in addition to anti-inflammatory activity. The antioxidant and anti-inflammatory effects of Bifidobacterium bifidum were also assessed.

\section{MATERIALS AND METHODS}

\subsection{Plant materials}

Tomatoes, carrots, sweet potatoes, broccoli, green tea, rosemary herb, hazelnuts and walnuts were purchased from local markets (Egypt), while wheat germ was obtained from the South Cairo and Giza Milling Co., Egypt.

\subsection{Chemicals}

Freund's complete adjuvant (Sigma, USA) was used for the induction of adjuvant arthritis in rats.

\subsection{Animals}

Male Sprague Dawley rats were used in this study. The animals were kept individually in wire bottomed stainless steel cages; water and food were given ad-libtium. Adult normal male and female albino mice of 21-25 g body weight were used in an acute toxicity test.

\subsection{Diets}

A balanced diet composed of $10 \%$ protein supplemented from casein, 10\% corn oil, $23.5 \%$ sucrose, $47 \%$ maize starch, $5 \%$ fiber, $3.5 \%$ salt mixture (Briggs \& Williams, 1963) and 1\% vitamin mixture (Morcos, 1967) was prepared for feeding the rats throughout the experimental period.

\subsection{Preparation of plant materials}

Fresh tomatoes, carrots, sweet potatoes and broccoli were washed with tap water and cut into small pieces. All plant materials were dried separately in an air-circulated oven at $40^{\circ} \mathrm{C}$ to complete dryness and then reduced to powder form.

\subsection{Preparation of plant extracts}

The dried powder from tomatoes, carrots and sweet potatoes was separately placed in a continuous extraction apparatus and subjected to extraction using acetone for the extraction of carotenoids. Walnuts, hazelnuts and wheat germ were extracted individually by petroleum ether (40$60^{\circ} \mathrm{C}$ ) using soxhlet to extract the oil. Green tea, broccoli and rosemary were separately placed in a continuous extraction apparatus and subjected to crude extraction using methanol. The solvent of each extract was completely removed by evaporation under reduced pressure. All extracts were kept in deep freeze until use.

\subsection{Preparation of mixtures and dosage form}

Three mixtures were prepared from the previously prepared extracts. Mixture (1) contains the crude methanol extract of green tea, wheat germ oil and the acetone extract of tomato. The crude methanol extract of rosemary, walnut oil and the acetone extract of sweet potato were the ingredients of mixture (2). The components of mixture (3) were the crude methanol extract of broccoli, hazelnut oil and the acetone extract of carrot. For the preparation of dosages for the animal experiment, each mixture was prepared separately in water using gum acacia. For the control, the vehicle was prepared by dissolving the same amount of gum acacia in water.

\subsection{Chemical analysis of the mixtures}

Tocopherols ( $\alpha, \gamma$ and $\delta$ ) were determined in each mixture according to the method of Amaral et al. (2005) using HPLC. An HPLC/Agilent model, Agilent 1100 G 1311A Quat pump, G1322A Degasser, G 1329A Autosampler, G 1330A Chiller, G 1316A column compartment, fluorescence detector PC and Chemstation software were used with an SI $(150 \times 4.6 \mathrm{~mm})$ column. The wave length of excitation was set at $290 \mathrm{~nm}$ and emission at $330 \mathrm{~nm}$. The mobile phase was a mixture of 
hexane and isopropanol (99:1, v/v), at a flow rate of $1 \mathrm{ml} / \mathrm{min}$. The concentrations of $\alpha, \gamma$ and $\delta$-tocopherols in the samples were obtained by comparing their peak areas with the peak area of standards in relation to concentration.

Beta-Carotene was determined according to the method of Simpson et al. (1985).

Total phenolics were determined colorimetricaly in the plant extract mixtures using the Folin-Ciocalteu reagent (Singleton \& Rossi. 1965). Absorbance was measured at $765 \mathrm{~nm}$ using a UVPC spectrophotometer. The total phenolic content was expressed as gram gallic acid equivalent (GAE) per 100 gram mixture.

\subsection{Bacterial culture}

Bifidobacterium bifidum (obtained from Chr. Hansen s Lab. Denmark) was maintained in sterile skimmed milk, supplemented with $1 \%$ dextrose and $0.1 \%$ yeast extract (Misra \& Kuila, 1992) and were subcultured three times in MRS broth for activation before being ingested by the rats.

\subsection{Induction of Adjuvant arthritis in rats}

Thirty-six male rats with an average body weight of $131 \pm 1.955 \mathrm{~g}$ were divided into six groups, each comprised of six rats. Four groups served as the test groups. The rats in three of the test groups were given a daily oral dose of mixture 1, 2 or 3 as $250 \mathrm{mg} / \mathrm{kg}$ rat body weight. The rats in the fourth test group received a daily oral dose of $0.8 \mathrm{ml}$ of milk containing $10^{9}$ Bifidobacterium bifidum as probiotic. The rats in the two control groups were only given daily equal amounts of the vehicle received by the test groups. All treatments were given by stomach tubes. On the eighth day after starting dosage, adjuvant arthritis was induced by injection of Freund's complete adjuvant into the subplanter region of the right hind-foot paw of rats of all groups except one control group, which served as the normal control (Singh et al., 1992). The rats were kept on the balanced diet throughout the experiment. Paw thickness was measured immediately before induction of arthritis and three times per week using vernier caliper to assess the degree of inflammation. At the end of the experiment, the increase in the thickness of the injected foot (inflammation) of the rats of test groups was compared with that of the arthritic control. During the experiment, body weights and food intake were recorded twice weekly. At the end of the experiment, total food intake, body weight gain and food efficiency ratio (body weight gain/ total food intake) were calculated. After the experimental period, the rats fasted for 16 hours; one gram of faeces was collected from each rat in a sterile tube for the determination of microflora. Blood samples were withdrawn from the eye vein orbital of anaesthetized rats. The blood samples of arthritic rats and the normal healthy control rats were divided into three parts. One was mixed with trisodium citrate $(109 \mathrm{mmol} / \mathrm{L})$ for the determination of erythrocyte sedimentation rate (ESR), an inflammatory biomarker, (Westergren, 1921). The second part was mixed with heparin for the separation of plasma to determine the total antioxidant capacity (TAC), an antioxidant biomarker (Koracevic et al., 2001), tumor necrosis factor- $\alpha$ (TNF- $\alpha$ ) (an inflammatory biomarker) (Stepaniak et al., 1995) and malondialdehyde (MDA) as indicator of lipid peroxidation (Satoh, 1978). For determination of the activity of erythrocyte superoxide dismutase (SOD) (Roth \& Gilgert, 1984), saline was added to the red cell layer of the centrifugate. The red cells were cenrtifuged and washed three times with saline and stored at $-20^{\circ} \mathrm{C}$ until analyzed. The third part of the blood was mixed with heparin for the determination of glutathione peroxidase (GPx) as antioxidant biomarker (Pleban et al., 1982). All rats were kept alive for an additional 24 hours and injected intrapritoneally with $3 \mathrm{ml}$ colchicine $(0.2 \mathrm{~g} / 100 \mathrm{ml}$. saline). After 2 hours of injection, bon marrow was separated and a cytogenetic assessment was carried out immdiately. After 4 hours of injection, the spleen and liver were separated, weighed and processed immediately for cytogenetic tests. The animal experiment was conducted according to the Medical Research Ethics Committee, National Research Center, Cairo, Egypt.

\subsection{Microbiological study on faeces}

The fecal sample $(1 \mathrm{~g})$ was placed in a $9 \mathrm{~mL}$ diluted Ringer solution (which contained cysteine), homogenized and serially diluted with 10-fold dilutions using prereduced buffered peptone $(20 \mathrm{~g} / \mathrm{L}$ buffered peptone Oxoid $\mathrm{CM} 509,0.5 \%$ cysteine $\mathrm{HCl}$ and $0.1 \%$ Tween 80 ). The faeces were microbiologically analyzed for Bifidobacteria count using MannRogosa-Sharpe (MRS) agar (Oxoid) supplemented with $0.05 \%$ L-cysteine $\mathrm{HCl}$ (Blanchette et al., 1996). A coliform count was carried out using MacConkey agar while a Staphylococci count was implemented using Baird-Parker medium base, supplemented with egg yolk and potassium tellurite. The plates for anaerobic bacteria were incubated for $48 \mathrm{~h}$ at $37^{\circ} \mathrm{C}$ in an anaerobic atmosphere using Gen Kits in Oxoid jars. The plates for aerobic bacteria were incubated aerobically for $48 \mathrm{~h}$ at $37^{\circ} \mathrm{C}$. At the mentioned time, the colony forming units (CFU) on each plate were counted and calculated with reference to the original weight of the samples. The results were expressed as $\log 10 \mathrm{CFU} / \mathrm{g}$ of feces.

\subsection{Assessment of Cytogenetic parameters}

\section{Chromosomal aberration test for somatic and germ cells}

Somatic cell: Bone marrow metaphases were prepared following the method of Yosida and Amano (1965) and stained with the phosphate buffer Giemsa. Gaps, fragments, breaks, centricfusions and numerical aberrations were scored. 
Germ cells: For preparation of spermatocytes at diakinasis metaphase I, the test specimens were dissected and processed according to Evans et al. (1964). Metaphases with $X-Y$ and autosomal univalents, breaks and /or fragments and gap $x-y$ were scored. 100 well-spread metaphases were analyzed per animal.

\section{DNA fragmentation assay}

The method of DNA fragmentation was carried out according to Perandones et al. (1993). The liver tissues $(200 \mathrm{mg})$ were mechanically dissociated in $400 \mu \mathrm{L}$ hypotonic lysis buffer to obtain cell lysate. The cell lysate was centrifuged at $13.800 x g$ for 15 minutes. The supernatant containing small DNA fragments was separated immediately and half the supernatant was used for gel electrophoresis. The other half, as well as the pellet containing large pieces of DNA, were used for the diphenylamine (DPA) assay.

Diphenylamine assay (DPA). The colorimetric determination of DNA content was carried out according to Perandones et al. (1993) with some modifications from Burton (1956). Both the supernatant and the pellet were used for the DPA assay after the acid extraction of DNA. The pellet containing large fragments of DNA and cell debris was resuspended in $400 \mu$ hypotonic lysis buffer. $400 \mu \mathrm{l}$ of $10 \%$ Trichloroacetic acid (TCA) was added to both the other half of the supernatant and the re-suspended pellet. The tubes were centrifuged at $2000 \mathrm{rpm}$ for $10 \mathrm{~min}$. The precipitate was resuspended in $400 \mu \mathrm{l}$ of $5 \%$ TCA. The tubes were incubated at $80^{\circ} \mathrm{C}$ for $30 \mathrm{~min}$. The supernatant containing the extracted DNA was left to cool at room temperature. Two volumes of the color reagent were added to one volume of the extracted DNA. The samples were stored at $4^{\circ} \mathrm{C}$ for $48 \mathrm{~h}$ till the blue color developed. The blue color was measured colorimetrically using spectrophotometer at $578 \mathrm{~nm}$. The percentage of DNA fragmentation in each sample was expressed by the formula:

$\%$ DNA fragmentation $=$ OD of supernatant $\times$ $\times 100 /$ OD of supernatant + OD of pellet

Where OD is the optical density.

Gel Electrophoresis. One half of the supernatant was treated with an equal volume of absolute isopropanol and $0.5 \mathrm{M} \mathrm{NaCl}$ to precipitate the DNA. The samples were stored at $-20^{\circ} \mathrm{C}$ overnight and centrifuged at $13.800 \mathrm{xg}$ for 15 minutes. The pellet was washed with $200 \mu$ of $70 \%$ ethanol, and then allowed to dry at room temperature. The DNA was resuspensed with $12 \mu \mathrm{l}$ of Tris-EDTA solution and $3 \mu \mathrm{L}$ loading buffer, incubated at $37^{\circ} \mathrm{C}$ for $20 \mathrm{~min}$, then electrophoresed on $1 \%$ agarose gel containing $0.71 \mu \mathrm{g} / \mathrm{ml}$ of ethidium bromide for $1 \mathrm{~h}$. The gels were photographed using a Polaroid camera under UV Transilluminator.

\section{DNA extraction}

DNA was extracted from the spleen tissue using the AxyPrep Multisource Genomic DNA Miniprep
Kit purchased from Axygen Biosciences (33210 Central Avenue, Union City , CA 94587 USA).The whole genome was electrophoresed on 1.5\% agarose gel containing $0.5 \mathrm{ug} / \mathrm{ml}$ of ethidium bromide for $1 \mathrm{~h}$. The Gel was photographed using a Polariod camera under a UV Transilluminator. The intensity of apoptotic bands was measured using the software gel Pro program analyzer version 3.1 as maximum optical density values.

\subsection{Acute toxicity test}

An acute lethal toxicity test of the extract mixtures was carried out according to Goodman et al. (1980). The $24 \mathrm{~h}$ mortality counts among equal sized groups of mice (8 animals/group) receiving progressively increasing oral dose levels of the different extracts were recorded.

\subsection{Statistical analysis}

The results of the animal experiments and microbiological study were expressed as the mean \pm SE. The results were analyzed statistically using one-way analysis of variance ANOVA followed by Duncan's test. In all cases $p<0.05$ was used as the criterion of statistical significance. For statistical analysis of somatic and germ cells the Chi-square test $(2 \times 2$ contingency table $)$ was applied. Student's t-test was applied to the data of DNA fragmentation in liver cells.

\section{RESULTS}

\subsection{Chemical analysis of the mixtures}

Tocopherols, $\beta$-carotene and the phenolic compound contents in the studied mixtures are shown in table 1. Alpha-tocopherol was shown to be $266.290,71.50$ and $54.70 \mathrm{mg} / 100 \mathrm{~g}$ in mixtures (1), (2) and (3) respectively. Gamma-tocopherol was present in mixtures (1), (2) and (3) as 98.440, 6.38 and $0.73 \mathrm{mg} / 100 \mathrm{~g}$ respectively. Mixture (1) showed the highest content of $\delta$-tocopherol (193.30 $\mathrm{mg} / 100 \mathrm{~g}$ ), while mixture (2) showed the lowest

Table 1

Tocopherols, $\beta$-carotene and phenolic contents of the studied mixtures

\begin{tabular}{lccc}
\hline $\begin{array}{c}\text { Ingredients/100g } \\
\text { sample }\end{array}$ & $\begin{array}{c}\text { Mixture } \\
\mathbf{( 1 )}\end{array}$ & $\begin{array}{c}\text { Mixture } \\
\mathbf{( 2 )}\end{array}$ & $\begin{array}{c}\text { Mixture } \\
\mathbf{( 3 )}\end{array}$ \\
\hline $\begin{array}{c}\text { Tocopherols (mg): } \\
\alpha \text { - tocopherol }\end{array}$ & 266.290 & 71.50 & 54.70 \\
$\gamma$ - tocopherol & 98.440 & 6.38 & 0.73 \\
$\delta$ - tocopherol & 193.30 & 0.54 & 54.90 \\
$\beta$-carotene (mg) & 0.530 & 37.454 & 33.950 \\
Total phenolic & 3.97 & 3.34 & 2.57 \\
compounds (g as GAE) & & & \\
\hline
\end{tabular}


content $(0.54 \mathrm{mg} / 100 \mathrm{~g})$. Mixture (3) contained $54.90 \mathrm{mg} \delta$-tocopherol $/ 100 \mathrm{~g}$. Total phenolic contents were $3.97,3.34$ and $2.57 \mathrm{~g}$ as $\mathrm{GAE} / 100 \mathrm{~g}$ of mixtures (1), (2) and (3) respectively. $\beta$-carotene was shown to be $0.530,37.454$ and $33.950 \mathrm{mg} / 100 \mathrm{~g}$ of mixtures (1), (2) and (3), respectively. On the other hand, mixture (1) containing the acetone extract of tomatoes is expected to contain lycopene (carotenoid) reported previously to present $35 \pm 1.3 \mathrm{mg} / 100 \mathrm{~g}$ of dry tomatoes (Toor \& Savage, 2006).

\subsection{Inflammation thickness}

The thickness of the injected foot paw of the different studied groups during the period of experiment is seen in figure 1. The injection of Freund's complete adjuvant produced an inflammation which reached its maximum after the first 3 days of injection (11 days from the start of the experiment), thereafter; the swelling slowly subsided until the ninth day of injection (15 days from the start of the experiment) and remained almost steady to the thirteenth day of injection (the end of the experiment). It was noticed that the oral administration of different mixtures of extracts or milk containing probiotic produced a significant reduction in the hind paw inflammation throughout the experiment.

The increase in foot thickness (Thickness of inflammation) of the control arthritic rats at the end of the experiment compared with that of the rats given the different treatments is presented in Table 2. To deduce the thickness of inflammation in the rats of each group, the foot thickness at the start of the experiment was subtracted from that at the end of the experiment. Oral administration of extract mixtures or probiotic suppressed the swelling in the foot significantly compared to the arthritic control. Non-significant changes were observed between arthritic rats given plant mixtures or probiotic. Extract mixtures produced a reduction in inflammation ranging from 36 to $48 \%$. Bifidobacterium bifidum produced a reduction in inflammation by $29 \%$. Mixture 3 was superior in this respect followed by mixture (2) then mixture (1).

\subsection{Biochemical and Nutritional Parameters of Arthritic Rats}

The results of the biochemical changes in arthritic rats given different treatments are shown in Table 3. ESR, erythrocyte SOD activity and the plasma levels of MDA and TNF- $\alpha$ were significantly higher in arthritic control rats than the normal control. Plasma levels of TAC and GPx activity were significantly lower in arthritic control rats than the normal control.

ESR and the plasma levels of TNF- $\alpha$ and erythrocyte SOD activity in arthritic rats decreased significantly in arthritic rats given the different treatments compared to the control arthritic rats but still significantly higher than the normal control. TAC increased significantly in arthritic rats given oral administration of the different extract mixtures or Bifidobacterium bifidum, compared to the arthritic control. TAC was normalized with different treatments, since it did not show any significant change compared to the normal control. The plasma level of MDA reduced significantly in various treatments

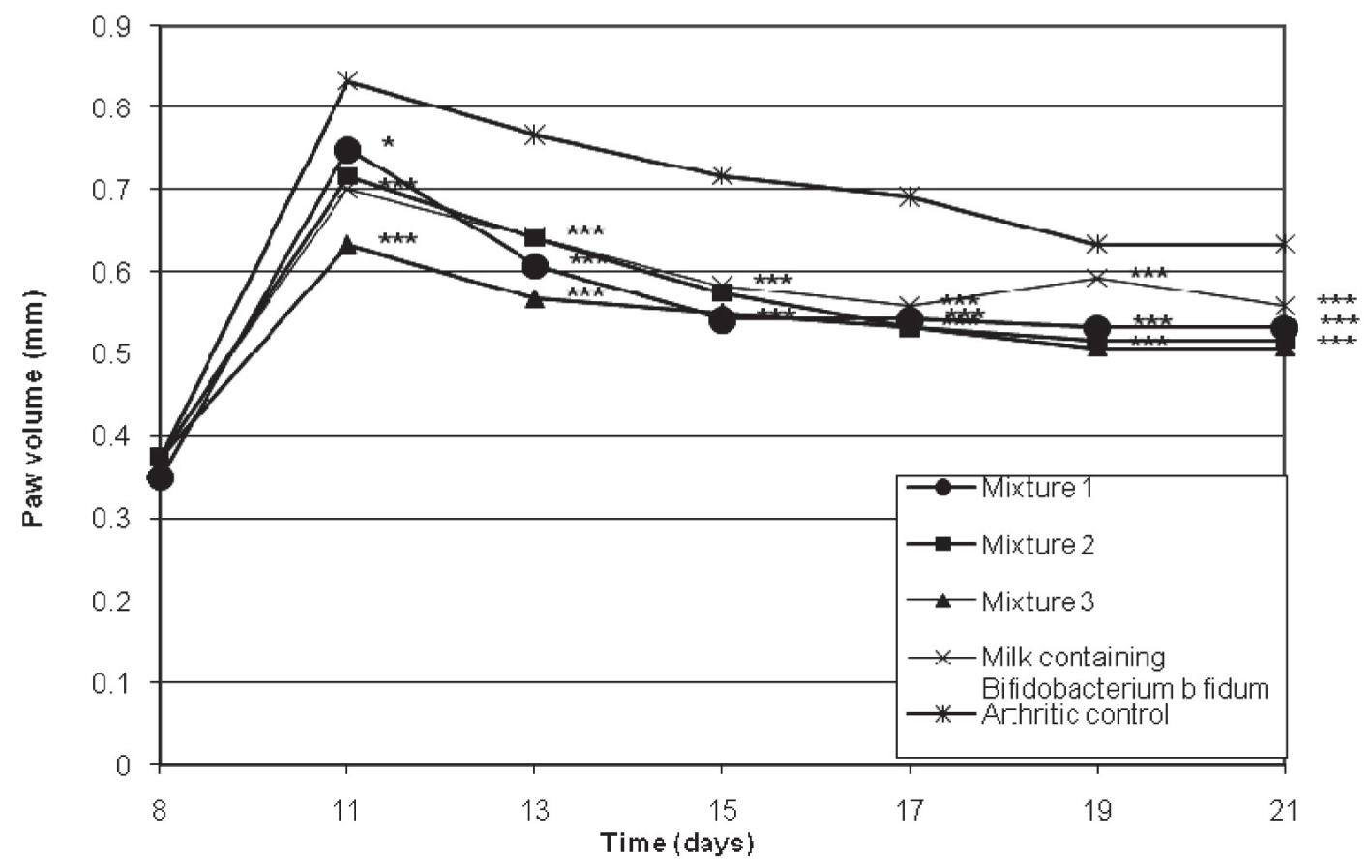

Figure 1

Paw volume $(\mathrm{mm})$ of different experimental groups of arthritic rats. Values significantly differ from arthritic control: ${ }^{*}: p<0.010,{ }^{* *}: p<0.005,{ }^{* * *}: p<0.001$. 
Table 2

The increase in the thickness of the injected foot (after 13 days of adjuvant arthritis induction) of arthritic rats given a daily oral dose of the different plant extract mixtures $(250 \mathrm{mg} / \mathrm{kg}$ rat body weight) or $10^{9}$ Bifidobacterium bifidum /day

\begin{tabular}{lcc}
\hline \multicolumn{1}{c}{ Groups } & Mean \pm SE & $\begin{array}{c}\text { \% Inhibition of } \\
\text { inflammation }\end{array}$ \\
\hline Arthritic control & $0.258^{\mathrm{a}} \pm 0.015$ & - \\
Mixture 1 & $0.167^{\mathrm{b}} \pm 0.025$ & 36 \\
Mixture 2 & $0.142^{\mathrm{b}} \pm 0.024$ & 45 \\
Mixture 3 & $0.133^{\mathrm{b}} \pm 0.028$ & 48 \\
$\begin{array}{l}\text { Milk containing } \\
\begin{array}{l}\text { Bifidobacteria } \\
\text { bifidum }\end{array}\end{array}$ & $0.183^{\mathrm{b}} \pm 0.011$ & 29 \\
\hline
\end{tabular}

In the same column different letters mean significant difference at 0.05 probability.

with different degrees compared with the arthritic control but still significantly higher than the normal control. Also, the blood levels of GPx activity increased significantly in arthritic rats given different treatments when compared with the arthritic control but was significantly lower than the normal control. The overall results show a reduction in oxidative stress and an increase in antioxidant state with different treatments as compared to the arthritic control.

The results of the nutritional parameters are shown in Table 4. Body weight gain and food efficiency ratio decreased significantly in the control rats with adjuvant arthritis and the arthritic rats given oral administration of mixtures (2), (3) or Bifidobacterium bifidum compared to the normal control and the arthritic rats given oral administration of mixture (1). Food intake was also reduced in the arthritic control but non-significantly. The arthritic rats given oral administration of mixture (1) showed a significant increase in body weight gain and food efficiency ratio when compared with different arthritic groups. Liver and spleen weights showed non-significant changes among all experimental groups.

\subsection{Colonic bacteria}

Table 5 showed the bacterial counts in faeces of different experimental groups which reflect the colonic bacteria profile. When the bacterial count of the control arthritic was compared to the control healthy group, Bifidobacteria showed a significant decrease, while the Coliform and Staphylococci counts showed non significant changes. When arthritic rats given different treatments were

Table 3

Biochemical parameters of different experimental groups

\begin{tabular}{|c|c|c|c|c|c|c|c|}
\hline Groups & & $\begin{array}{c}\text { ESR } \\
(\mathrm{mm} / \mathrm{h})\end{array}$ & $\begin{array}{c}\text { Plasma } \\
\text { TAC } \\
(\mathrm{mM} / \mathrm{l})\end{array}$ & $\begin{array}{c}\text { GPx } \\
(\mathrm{U} / \mathrm{g} \mathrm{Hb})\end{array}$ & $\begin{array}{l}\text { SOD } \\
\left(\mathrm{U} / \mathrm{g} \mathrm{Hb} \mathrm{Hb}^{\star}\right)\end{array}$ & $\begin{array}{c}\text { Plasma } \\
\text { TNF- } \alpha \\
\text { (pg/ml) }\end{array}$ & $\begin{array}{c}\text { Plasma } \\
\text { MDA } \\
\text { (nmo/l) }\end{array}$ \\
\hline \multirow{2}{*}{ Normal control } & Mean & $1.8^{\mathrm{a}}$ & $2.04^{\mathrm{a}}$ & $161.2^{\mathrm{a}}$ & $1190^{a}$ & $17.45^{\mathrm{a}}$ & $5.86^{\underline{a}}$ \\
\hline & $\pm \mathrm{SE}$ & \pm 0.307 & \pm 0.082 & \pm 1.352 & \pm 13.163 & \pm 0.359 & \pm 0.314 \\
\hline \multirow{3}{*}{ Arthritic control } & Mean & $7.5^{b}$ & $1.17^{b}$ & $145.7^{b}$ & $1495^{b}$ & $28.32^{b}$ & $13.15^{b}$ \\
\hline & $\pm S E$ & \pm 0.428 & \pm 0.098 & \pm 1.542 & \pm 11.759 & \pm 0.577 & \pm 0.437 \\
\hline & $\%$ Change & 317 & -43 & -10 & 26 & 62 & 124 \\
\hline \multirow{3}{*}{ Mixture (1) } & Mean & $4.2^{c}$ & $2.14^{\mathrm{a}}$ & $155.5^{c}$ & $1315^{c}$ & $21.52^{c}$ & $10.73^{c}$ \\
\hline & $\pm \mathrm{SE}$ & \pm 0.307 & \pm 0.142 & \pm 1.384 & \pm 11.759 & \pm 0.381 & \pm 0.304 \\
\hline & $\%$ Change & -44 & 83 & 7 & -12 & -24 & -18 \\
\hline \multirow{3}{*}{ Mixture (2) } & Mean & $5.0^{\circ}$ & $1.991^{\mathrm{a}}$ & $150.5^{c}$ & $1412^{c}$ & $24^{c}$ & $11.48^{c}$ \\
\hline & $\pm S E$ & \pm 0.365 & \pm 0.111 & \pm 0.764 & \pm 12.492 & \pm 0.378 & \pm 0.217 \\
\hline & $\%$ Change & -33 & 70 & 3 & -6 & -15 & -13 \\
\hline \multirow{3}{*}{ Mixture (3) } & Mean & $4.8^{c}$ & $2.03^{a}$ & $153.0^{c}$ & $1362^{c}$ & $23.07^{c}$ & $11.15^{c}$ \\
\hline & $\pm \mathrm{SE}$ & \pm 0.401 & \pm 0.085 & \pm 0.894 & \pm 20.065 & \pm 0.357 & \pm 0.284 \\
\hline & $\%$ Change & -36 & 74 & 5 & -9 & -19 & -15 \\
\hline \multirow{3}{*}{$\begin{array}{l}\text { Milk containing } \\
\text { Bifidobacterium bifidum }\end{array}$} & Mean & $5.0^{c}$ & $1.96^{\underline{a}}$ & $152.0^{\circ}$ & $1374^{c}$ & $24.37^{c}$ & $11.65^{c}$ \\
\hline & $\pm S E$ & \pm 0.365 & \pm \pm 0.058 & \pm 1.118 & \pm 6.471 & \pm 0.321 & \pm 0.374 \\
\hline & $\%$ Change & -33 & 68 & 4 & -8 & -14 & -11 \\
\hline
\end{tabular}

In the same column different letters mean significant difference at 0.05 probability. \% Change calculated in comparison to arthritic control. ${ }^{*}: \mathrm{Hb}=$ Hemoglobin. 
Table 4

Nutritional parameters of different experimental groups

\begin{tabular}{lcccccccc}
\hline Groups & Mean & $\begin{array}{c}\text { Initial } \\
\text { body } \\
\text { weight (g) }\end{array}$ & $\begin{array}{c}\text { Final } \\
\text { body } \\
\text { weight (g) }\end{array}$ & $\begin{array}{c}\text { Body } \\
\text { weight } \\
\text { gain (g) }\end{array}$ & $\begin{array}{c}\text { Total } \\
\text { food } \\
\text { intake (g) }\end{array}$ & $\begin{array}{c}\text { Food } \\
\text { efficiency } \\
\text { ratio }\end{array}$ & $\begin{array}{c}\text { Liver } \\
\text { weight (g) }\end{array}$ & $\begin{array}{c}\text { Spleen } \\
\text { weight (g) }\end{array}$ \\
\hline \multirow{2}{*}{ Normal control } & $\pm \mathrm{SE}$ & \pm 8.039 & \pm 8.270 & \pm 4.184 & \pm 6.564 & \pm 0.0089 & \pm 0.3556 & \pm 0.1153 \\
\hline \multirow{2}{*}{ Arthritic control } & Mean & $128.8^{\mathrm{a}}$ & $168^{\mathrm{a}}$ & $39.2^{\mathrm{b}}$ & $358.2^{\mathrm{a}}$ & $0.1088^{\mathrm{b}}$ & $7.3^{\mathrm{a}}$ & $1.4^{\mathrm{a}}$ \\
& $\pm \mathrm{SE}$ & \pm 5.996 & \pm 9.174 & \pm 5.088 & \pm 4.174 & \pm 0.0131 & \pm 0.4768 & \pm 0.1424 \\
\hline \multirow{2}{*}{ Mixture 1 } & Mean & $128.3^{\mathrm{a}}$ & $190.8^{\mathrm{a}}$ & $62.5^{\mathrm{a}}$ & $366.7^{\mathrm{a}}$ & $0.169^{\mathrm{a}}$ & $7.9^{\mathrm{a}}$ & $1.2^{\mathrm{a}}$ \\
& $\pm \mathrm{SE}$ & \pm 7.259 & \pm 8.406 & \pm 7.582 & \pm 3.702 & \pm 0.019 & \pm 0.3899 & \pm 0.1591 \\
\hline \multirow{2}{*}{ Mixture 2 } & Mean & $128.3^{\mathrm{a}}$ & $172.3^{\mathrm{a}}$ & $44^{\mathrm{b}}$ & $363.2^{\mathrm{a}}$ & $0.1201^{\mathrm{b}}$ & $7.1^{\mathrm{a}}$ & $1.0^{\mathrm{a}}$ \\
& $\pm \mathrm{SE}$ & \pm 4.744 & \pm 8.267 & \pm 6.334 & \pm 6.062 & \pm 0.0156 & \pm 0.3934 & \pm 0.0347 \\
\hline \multirow{2}{*}{ Mixture 3 } & Mean & $128.5^{\mathrm{a}}$ & $178.3^{\mathrm{a}}$ & $49.8^{\mathrm{b}}$ & $361.5^{\mathrm{a}}$ & $0.1369^{\mathrm{b}}$ & $6.9^{\mathrm{a}}$ & $0.966^{\mathrm{a}}$ \\
& $\pm \mathrm{SE}$ & \pm 4.923 & \pm 9.771 & \pm 5.293 & \pm 4.997 & \pm 0.0128 & \pm 0.7246 & \pm 0.1517 \\
\hline Milk containing & Mean & $128^{\mathrm{a}}$ & $181.2^{\mathrm{a}}$ & $53.2^{\mathrm{b}}$ & $354^{\mathrm{a}}$ & $0.1508^{\mathrm{b}}$ & $6.7^{\mathrm{a}}$ & $0.826^{\mathrm{a}}$ \\
Bifidobacterium bifidum & $\pm \mathrm{SE}$ & \pm 2.744 & \pm 8.517 & \pm 7.142 & \pm 3.366 & \pm 0.0208 & \pm 0.3131 & \pm 0.0848 \\
\hline
\end{tabular}

In the same column different letters mean significant difference at 0.05 probability.

Table 5

Microflora in the different experimental groups $\left(\log _{10} \mathrm{CFU} / \mathrm{g}\right)$

\begin{tabular}{lcccccc}
\hline \multirow{2}{*}{ Strains } & \multicolumn{5}{c}{ Rats Groups (Mean \pm SE) } \\
\cline { 2 - 7 } & $\begin{array}{c}\text { Normal } \\
\text { control }\end{array}$ & $\begin{array}{c}\text { Arthritic } \\
\text { control }\end{array}$ & Mixt. (1) & Mixt. (2) & Mixt. (3) & $\begin{array}{c}\text { Bifidobacterium } \\
\text { bifidum }\end{array}$ \\
\hline Bifidobacteria & $8.0^{\mathrm{a}} \pm 0.05$ & $5.9^{\mathrm{b}} \pm 0.05$ & $7.6^{\mathrm{a}} \pm 0.31$ & $5.5^{\mathrm{b}} \pm 0.47$ & $7.0^{\mathrm{c}} \pm 0.28$ & $7.8^{\mathrm{a}} \pm 0.24$ \\
Coliform & $7.0^{\mathrm{a}} \pm 0.45$ & $6.3^{\mathrm{a}} \pm 0.33$ & $4.4^{\mathrm{b}} \pm 0.23$ & $5.4^{\mathrm{c}} \pm 0.31$ & $6.5^{\mathrm{a}} \pm 0.28$ & $5.7^{\mathrm{cd}} \pm 0.37$ \\
Staphylococci & $6.9^{\mathrm{a}} \pm 0.05$ & $6.2^{\mathrm{a}} \pm 0.41$ & $5.1^{\mathrm{b}} \pm 0.18$ & $5.2^{\mathrm{bc}} \pm 0.43$ & $5.9^{\mathrm{bc}} \pm 0.08$ & $5.6^{\mathrm{ab}} \pm 0.30$ \\
\hline
\end{tabular}

In each row different letters mean significant difference at 0.05 probability.

compared to the control arthritic rat, it was noticed that Bifidobacteria count increased significantly except in rats given mixture 2 , which showed a non significant change. Whereas Coliform and Staphylococci count showed only a significant reduction after administration of mixture 1 , the other treatments showed non significant changes in both counts compared to the arthritic control.

Non significant differences in the Bifidobacteria count were noticed when the arthritic rats of the group given mixture 1 or probiotic were compared with the healthy control group, which meant that these treatments normalized the Bifidobacteria counts in the arthritic control so that they match the normal count; while the count was significantly lower, $2.5 \mathrm{Log}$ and $1 \mathrm{Log}$ unit, in groups 2 and 3 respectively than the healthy control group. A significant decrease in the Coliform count was noticed when all test groups were compared with the healthy control group, except for mixture 3, where the decrease was non significant. Also, a significant reduction in the Staphylococci count was shown in all the groups given the extract mixtures compared to the healthy control group. In the case of the rats administered Bifidobacterium bifidum, no significant change was noticed in the Staphylococci count compared to the healthy control group.

\subsection{Cytogenetic Study}

In the present study, the synergistic effects of phenolic, tocopherols and carotenoid compounds (present in the prepared mixtures) were evaluated as protective antioxidants towards cytogenetic changes in somatic and germ cells of adjuvant arthritic rats in comparison to Bifidobacterium bifidum. Table 6 represents the number and percentage of structural and numerical chromosomal aberrations induced in rat bone-marrow cells (somatic cells). Table 7 illustrates the number and percentage of diakinesis metaphase I cells (germ cells). The percentage of total chromosomal aberrations was highly significant $(p<0.001)$ in the arthritic control group compared to the normal control. Fig 2 showed metaphases from the control adjuvant 
Table 6

Number and mean percentage of chromosomal aberrations in rat bone-marrow cells of the different experimental groups

\begin{tabular}{|c|c|c|c|c|c|c|c|c|c|c|c|c|c|c|c|c|c|}
\hline \multirow{3}{*}{ Treatment } & \multicolumn{8}{|c|}{$\begin{array}{l}\% \text { of cells with different types } \\
\text { of structural aberrations }\end{array}$} & \multicolumn{4}{|c|}{$\begin{array}{c}\% \text { of cells with } \\
\text { different } \\
\text { types of numerical } \\
\text { aberrations }\end{array}$} & \multicolumn{4}{|c|}{$\begin{array}{c}\text { Total Chromosomal } \\
\text { Aberrations }\end{array}$} & \multirow{3}{*}{$\begin{array}{l}\text { Inhibition } \\
\%\end{array}$} \\
\hline & \multicolumn{2}{|c|}{ Gap } & \multicolumn{2}{|c|}{ Br or F. } & \multicolumn{2}{|c|}{ Del. } & \multicolumn{2}{|c|}{ C.F. } & \multicolumn{2}{|c|}{ Endo. } & \multicolumn{2}{|c|}{ Tetra. } & \multicolumn{2}{|c|}{$\begin{array}{l}\text { Including } \\
\text { Gaps }\end{array}$} & \multicolumn{2}{|c|}{$\begin{array}{l}\text { Excluding } \\
\text { Gaps }\end{array}$} & \\
\hline & No. & $\%$ & No. & $\%$ & No. & $\%$ & No. & $\%$ & No. & $\%$ & No. & $\%$ & No. & $\%$ & No. & $\%$ & \\
\hline Normal control & 12 & 2.0 & 4 & 0.67 & 00 & 0.00 & 00 & 0.00 & 3 & 0.50 & 9 & 1.50 & 26 & 4.60 & 14 & 2.30 & \\
\hline Arthritic control & 20 & 3.33 & 17 & 2.83 & 10 & 1.67 & 3 & 0.50 & 6 & 1.00 & 16 & 2.67 & $72^{* * *}$ & 12.00 & $52^{* * * *}$ & 8.67 & \\
\hline Mixture (1) & 12 & 2.0 & 11 & 1.83 & 8 & 1.33 & 2 & 0.33 & 2 & 0.33 & 11 & 1.83 & $46^{\# \#}$ & 7.67 & $34^{\#}$ & 5.67 & 36 \\
\hline Mixture (2) & 12 & 2.0 & 11 & 1.83 & 9 & 1.50 & 1 & 0.17 & 3 & 0.50 & 13 & 2.17 & $49^{\# \#}$ & 8.17 & $37^{\#}$ & 6.17 & 32 \\
\hline Mixture (3) & 13 & 2.17 & 13 & 2.17 & 7 & 1.17 & 2 & 0.33 & 3 & 0.50 & 12 & 2.00 & $50^{\#}$ & 8.33 & $37^{\#}$ & 6.17 & 31 \\
\hline $\begin{array}{l}\text { Milk containing } \\
\text { Bifidobacterium } \\
\text { bifidum }\end{array}$ & 22 & 3.67 & 20 & 3.33 & 8 & 1.33 & 3 & 0.5 & 6 & 1.00 & 18 & 3.00 & 77 & 12.83 & 55 & 9.17 & \\
\hline
\end{tabular}

Br: Breaks, F: Fragments, Del.: Deletions, C.F.: Centric Fusions, Endo.: Endomitosis, Tetra.: Tetraploidy. Values significantly differ from healthy control: ${ }^{\star *} \mathrm{P}<0.001$. Values significantly differ from adjuvant arthritic control: \#: $\mathrm{P}<0.05, \# \#: \mathrm{P}<0.01$.

Table 7

Number and percentage of different types of diakinase metaphase I cells with chromosomal aberrations in rat spermatocytes of different experimental groups

\begin{tabular}{|c|c|c|c|c|c|c|c|c|c|c|c|c|c|}
\hline \multirow{3}{*}{ Treatment } & \multicolumn{10}{|c|}{$\%$ of cells with different types of chromosomal aberrations } & \multirow{2}{*}{\multicolumn{2}{|c|}{$\begin{array}{c}\text { Total } \\
\text { Chromosomal } \\
\text { Aberrations } \\
\end{array}$}} & \multirow{3}{*}{$\begin{array}{c}\text { Inhibition } \\
\%\end{array}$} \\
\hline & \multicolumn{2}{|c|}{$x-y$ uni. } & \multicolumn{2}{|c|}{ Auto.uni. } & \multicolumn{2}{|c|}{ X-Y+Auto. } & \multicolumn{2}{|c|}{ Fr.\&/orBr. } & \multicolumn{2}{|c|}{ Gap inX-Y } & & & \\
\hline & No. & $\%$ & No. & $\%$ & No. & $\%$ & No. & $\%$ & No. & $\%$ & No. & $\%$ & \\
\hline Normal control & 17 & 2.83 & 8 & 1.33 & 00 & 0.00 & 00 & 0.00 & 00 & 0.00 & 25 & 4.17 & \\
\hline Arthritic control & 20 & 3.33 & 15 & 2.50 & 13 & 2.17 & 4 & 0.67 & 4 & 0.67 & $56^{* * *}$ & 9.33 & \\
\hline Mixture (1) & 18 & 3.00 & 12 & 2.00 & 6 & 1.00 & 3 & 0.50 & 1 & 0.17 & $40^{\#}$ & 6.67 & 29 \\
\hline Mixture (2) & 20 & 3.33 & 10 & 1.67 & 8 & 1.33 & 2 & 0.33 & 00 & 0.00 & $40^{\#}$ & 6.67 & 29 \\
\hline Mixture (3) & 15 & 2.50 & 10 & 1.67 & 8 & 1.33 & 3 & 0.50 & 2 & 0.33 & $38^{\#}$ & 6.33 & 32 \\
\hline $\begin{array}{l}\text { Milk containing } \\
\text { Bifidobacterum } \\
\text { bifidum }\end{array}$ & 25 & 4.17 & 15 & 2.50 & 12 & 2.00 & 3 & 0.50 & 2 & 0.33 & 57 & 9.50 & \\
\hline
\end{tabular}

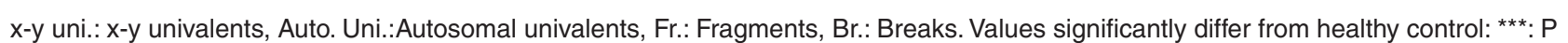
$<0.001$. Values significantly differ from adjuvant arthritic control: \#: $\mathrm{P}<0.05$.

arthritis rats; breaks and fragments in rat bonemarrow cells can be noticed in fig $2 \mathrm{a}$; and autosomal univalent in rat spermatocytes is shown in fig $2 \mathrm{~b}$. The administration of any of the tested mixtures significantly inhibited the percentage of chromosomal aberrations in somatic and germ cells compared to the control arthritic rats but still not matching the healthy control. The rats that received Bifidobacterium bifidum statisticaly recorded nonsignificant change in chromosomal aberrations compared to the control arthritic.

Table 8 demonstrates the mean percentage of DNA fragmentation in the rat liver cells of the different experimental groups. The percentage of DNA fragmentation was statistically significant $(p<$ 0.01) in theadjuvant arthritic control compared to the normal control. Administration of the different extract mixtures significantly reduced DNA fragmentation $(p<0.05)$ compared to the control arthritic. Agarose-gel electrophoresis (fig. 3) confirmed the inhibition percentage induced by the administration of different extract mixtures (37.09\%, $30.26 \%$ and $33.5 \%$ for mixtures 1,2 and 3 respectively). The administration of Bifidobacterium bifidum showed non significant changes in DNA fragmentation. 


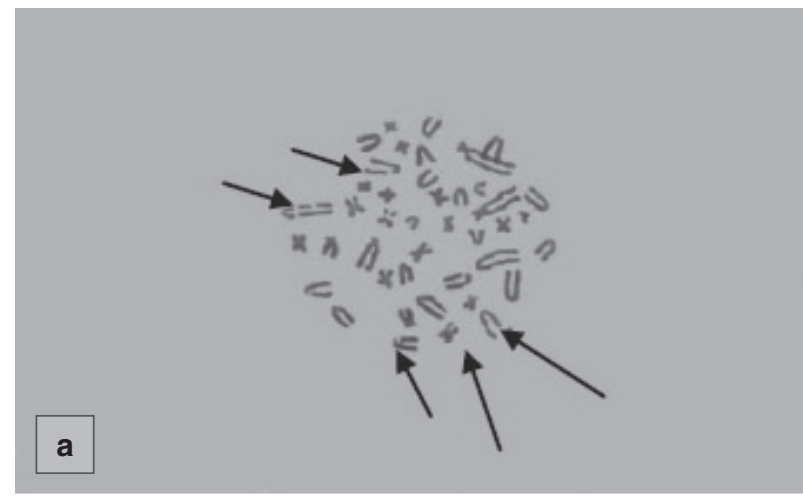

Figure $2 a$

Metaphases from control adjuvant arthritis rats showing breaks and fragments in rat bone-marrow cells.

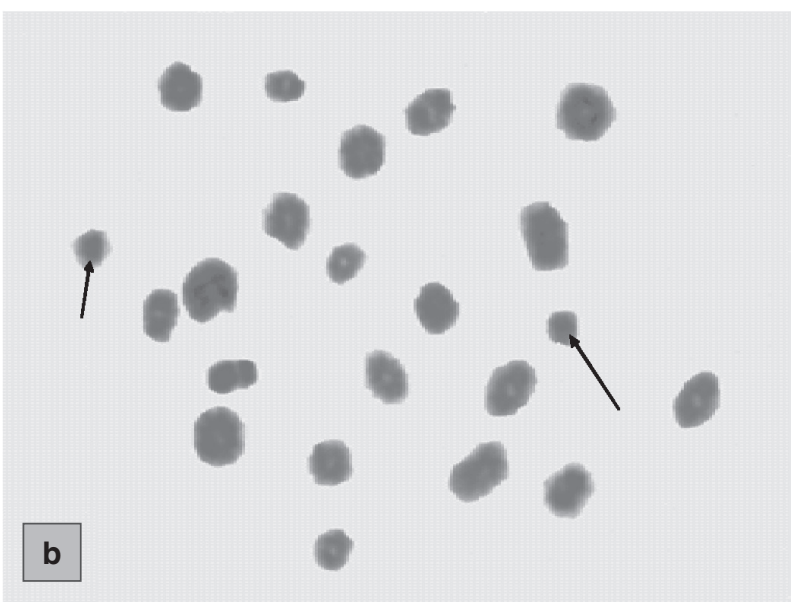

Figure $2 b$

Metaphases from control adjuvant arthritis rats showing autosomal univalent in rat spermatocytes.

Table 8

Mean percentage of DNA fragmentation induced in rat liver cells of different experimental groups

\begin{tabular}{lcc}
\hline \multicolumn{1}{c}{ Groups } & $\begin{array}{c}\text { DNA fragmentation } \% \\
\text { Mean } \pm \text { SE }\end{array}$ & $\begin{array}{c}\text { Inhibition } \\
\%\end{array}$ \\
\hline Normal control & $3.08 \pm 0.327$ & \\
Arthritic control & $11.70^{\star \star} \pm 0.672$ & \\
Mixture (1) & $7.36^{\#} \pm 0.210$ & 37.09 \\
Mixture (2) & $8.16^{\#} \pm 0.37$ & 30.26 \\
Mixture (3) & $7.78^{\#} \pm 0.250$ & 33.50 \\
$\begin{array}{l}\text { Milk containing } \\
\text { Bifidobacterium } \\
\text { bifidum }\end{array}$ & $12.10 \pm 0.139$ & \\
\hline
\end{tabular}

Values significantly differ from normal control: ${ }^{* *}: p<0.01$. Values significantly differ from arthritic control: $\#: p<0.05$.

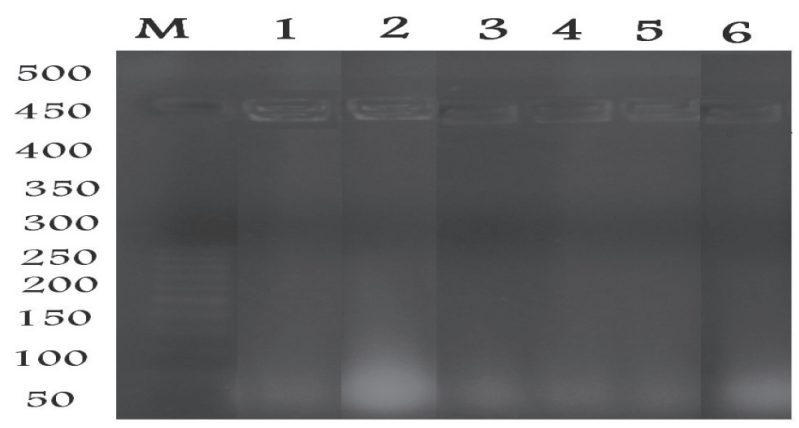

Figure 3

DNA fragmentation of rat liver cells of different groups. Lane M: 50 bp. DNA ladder, lane 1: normal control, lane 2: control adjuvant arthritis, lane 3, 4 \&5: adjuvant arthritis

+ mix.3, $1 \& 2$ respectively and lane 6 : adjuvant arthritis + Bifidobacterium bifidum.

As shown in Table 9 and fig. 4, the control arthritic rats showed DNA damage and apoptosis in the spleen lymphocytes of the rats. The optical density value at $600 \mathrm{bp}$ reached 54.86 in the control arthritic group compared to 9.73 for the healthy control and the recorded 41.68, 37.69, 46.95 and 13.5 optical densities for the rats given mixtures 1 , 2, 3 and Bifidobacterium bifidum respectively. This result shows that the DNA damage in arthritic rats was reduced after administration of the different mixtures and Bifidobacterium bifidum. In addition, the optical density value at 400 and 200 bp showed high values in arthritic rats compared to the normal control. This value decreased only after supplementation of mixture (2) and Bifidobacterium bifidum at bp 400 and after supplementation of mixtures (1) and (2) at bp 200.

The acute lethal toxicity test revealed that all studied extract mixtures were very safe up to $12 \mathrm{~g} / \mathrm{kg}$ mice body weight which corresponds to $93 \mathrm{~g} / 70 \mathrm{~kg}$ human body weight when the dose of mice was extrapolated to corresponding estimates in humans adopting the interspecies dosage conversion scheme (Paget \& Barnes, 1964). This reflects the high safety of the bioactive extracts.

\section{DISCUSSION}

In the present research, three extract mixtures of plant food were prepared. The plant food extracts were selected because they are rich in phenolic compounds, tocopherols and carotenoids, which are expected to have antioxidant and free radical scavenging capacity in addition to anti-inflammatory activity. The mixtures were evaluated in adjuvant arthritic rats to study their efficiency as protective agents towards chronic inflammatory disease. The synergistic antioxidant and anti-inflammatory effects of the bioactive constituents of the mixtures have been estimated through assessment of the 
Table 9

Optical density of apoptotic fragments of DNA at $200,400,600$ base pair (bp) in rat spleen lymphocytes of different experimental groups

\begin{tabular}{lrcc}
\hline \multirow{2}{*}{\multicolumn{1}{c}{ Groups }} & \multicolumn{3}{c}{$\begin{array}{c}\text { Molecular wt. } \\
\text { of apoptosis (bp) }\end{array}$} \\
\cline { 2 - 4 } & $\mathbf{6 0 0}$ & $\mathbf{4 0 0}$ & $\mathbf{2 0 0}$ \\
\hline Normal control & 9.73 & 8.52 & 14.86 \\
Arthritic control & 54.86 & 49.43 & 90.48 \\
Mixture (1) & 41.68 & 49.22 & 77.40 \\
Mixture (2) & 37.69 & 42.73 & 80.68 \\
Mixture (3) & 46.95 & 52.35 & 92.27 \\
$\begin{array}{l}\text { Milk containing } \\
\text { Bifidobacterium } \\
\text { bifidum }\end{array}$ & 13.5 & 39.2 & 91.8 \\
\hline
\end{tabular}

thickness of inflammation, specific biomarkers and colonic microflora and by evaluating their antimutagenic potency through cytogenetic parameters in an adjuvant arthritis model in rats.

Chronic inflammation is an important feature of many joint diseases, including rheumatoid arthritis (de Grauw et al., 2009). Adjuvant-induced arthritis is an animal model of chronic inflammation which is similar to rheumatoid arthritis in humans. It can be induced in rats by an intradermal injection of Freund's adjuvant. Adjuvant arthritis is characterized by inflammation, high oxidative stress and reduction in body weight (Ibáñez de Cáceres et al., 2000).

Induction of chronic inflammation in rats in the present work was reflected in the increased inflammatory biomarkers. The assessed inflammatory biomarkers, ESR and TNF- $\alpha$, showed extreme elevation in the control adjuvant arthritic rats compared to the normal control. This result was in agreement with the work of Glenn \& Kooyers (1966) and Mahajan et al. (2007).

The high activity of erythrocyte SOD and the reduction in GPx activity in the arthritic control

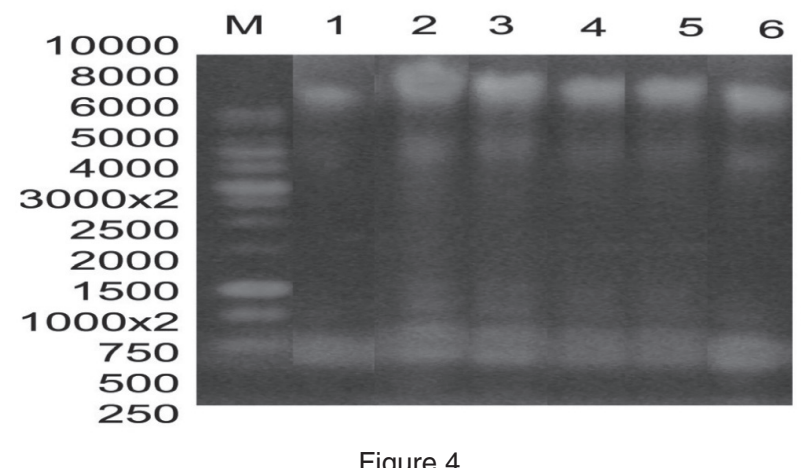

Effect of Adjuvant arthritis on rat spleen cells (DNA extract). Lane M: 200 bp. DNA ladder, lane 1: normal control,

lane 2: control adjuvant arthritis, lane 3, 4 \& 5: adjuvant arthritis + mix.3, $1 \& 2$ respectively: and lane 6 : adjuvant arthritis + Bifidobacterium bifidum. shown in the present study agree with the work of Tuncer et al. (1999) and Tastekin et al. (2007). The increase in SOD induced the scavenging of the superoxide ione into $\mathrm{H}_{2} \mathrm{O}_{2}$, a more potent reactive oxygen species, which may be accumulated due to a reduction in GPx resulting in increased lipid peroxidation which is reflected in the significant increase in MDA in the present study. Adjuvant arthritis is a condition that involves systemic oxidative stress (Strosova et al., 2009), which could be reflected by an elevation in SOD and a reduction in GPx levels in the present study, together with the reduction in TAC and increased MDA. The elevation in the plasma levels of MDA in the arthritic control rats in the current research is in agreement with the results of Tastekin et al. (2007).

The administration of extract mixtures or Bifidobacterium bifidum to arthritic rats produced significant improvements in inflammatory and oxidative stress biomarkers together with a reduction in inflammation thickness. These effects are certainly attributed to the presence of antioxidant and antiinflammatory constituents such as tocopherols, carotenoids and phenolic compounds in the mixtures used in the present study. The variation in improvements may be related to the different contents of such active constituents as well as to their synergistic effects.

The decrease in body weight gain and food efficiency ratio in the control rats with adjuvant arthritis compared to the normal control was expected since it has been reported that rheumatoid arthritis is usually associated with loss of lean tissues, which contain most of the body's protein (Bistrian \& Blackburn, 1983). The decrease in body weight gain in the arthritic control rats may be due to tissue destruction in adjuvant arthritic rats. The rates of protease-mediated degradation of muscle protein were accelerated without changes in protein synthesis in experimental arthritis (Fagan et al., 1987). Intracellular proteolysis of muscle proteins by lysosomal proteases is mediated by $\mathrm{PGE}_{2}$ the later increased during inflammation (Fagan et al., 1987). Also the reduction in body weight gain may be due to muscle wasting in experimental arthritis, which seems to be due to enhanced protein breakdown by the ubiquitin-proteasome proteolytic pathway (Lecker et al., 2004; Granado et al., 2005). It was noticed that food intake was also reduced, non-significantly, which may share in the reduction of body weight gain. It has been also reported that rheumatoid arthritis is associated with anorexia (Bistrian \& Blackburn, 1983). It was noticed that all treatments produced a slight increase in body weight gain and food efficiency ratio which was only significant in the case of mixture 1. The significant improvement in body weight gain in arthritic rats is an indicator for improvement in the adjuvant arthritis (Glenn \& Kooyers, 1966).

Previously, rheumatoid arthritis patients showed alterations in the colonic bacteria profile (Frizen, 1994). Bifidobacteria and lactobacteria administration proved to be beneficial in rheumatoid arthritis 
patients (Pishak, 1999) but the exact mechanism is not known. Oral bacteriotherapy with Lactobacillus $G G$ in juvenile chronic arthritis reduced faecal urease activity. Its increase is a prominent feature in such a disease, suggesting altered microflora in juvenile chronic arthritis (Malin et al., 1997). In the present study, the reduction in colonic Bifidobacteria in the control arthritic rats reflected an inverse relationship between inflammation and the content of colonic Bifidobaceria. This inverse relationship was confirmed after the administration of mixtures 1, 3 and probiotic which produced a significant reduction in inflammation and inflammatory biomarkers with a simultaneous significant increase in the colonic Bifidobacteria. Bifidobacterium has been shown previously to inhibit NF-KappaB in intestinal epithelial cells and to exihibit antiinflammatory effects (Kim et al., 2010). The increase in colonic beneficial bacteria such as Bifidibacteria together with the reduction in pathogenic bacteria has been related to the reduction of inflammatory biomarkers (Daddaoua et al., 2007; Vulevic et al., 2008). In the present study, the phenolic contents of the tested nutraceutical may be responsible for the reduction in fecal pathogenic bacteria (Coliform and Staphylococci) together with the increase in fecal Bifidobacteria, beneficial bacteria, which may be attributed to the reported antibacterial effect of phenolic compounds (Kim et al., 2009).

The present study indicated that adjuvant arthritis has a highly significant genotoxic effect on rat bonemarrow cells and spermatocytes. In respect to the types of aberration fragments and/or breaks, deletions and polyploidy scored at a high percentage. These results are in agreement with previous studies that reported the induction of structural and numerical aberrations in the synovial fibroblasts of patients with rheumatoid arthritis, osteoarthritis and other inflammatory joint diseases. While specific chromosomal aberrations were trisomy/polysomy of chromosome 7 , deletions and breakage were observed (Kinne et al., 2001). The separation of chromosome forming univalents were reported to be the most common type of aberrations in rat spermatocytes; $X$ and $Y$ were more often separated than autosomes (Allen et al., 1986). This type of abnormality has been discussed as a mechanism of male sterility (Rapp et al., 1977). The current work also indicated the apoptotic changes induced by adjuvant arthritis in rat liver and spleen cells by measuring the percentage of DNA fragmentation colorimetrically with (DPA) assay and confirming it with agarose gel-electrophoresis (Wyllie et al., 1980).

An increase in DNA damage was observed in arthritic rats when compared to the healthy control. This result agreed with the results of Mythilypriya et al. (2008). DNA damage may be attributed to elevated oxidative stress. Halliwell (2002) reported that the level of DNA damage in adjuvant arthritis appears to be in a range that could contribute significantly to mutation rates. Apoptosis is a form of programmed cell death shown to play a key role in normal development and oncogenesis. Because DNA fragmentation in apoptosis is internucleosomal, a characteristic "DNA ladder" can be visualized on gel electrophoresis as a series of fragments that are multiples of 180 to $200 \mathrm{bp}$ which are shown in spleen lymphocytes. In contrast, the random DNA cleavage in necrosis leads to a DNA smear on gel electrophoresis for liver cells (Wyllie et al., 1980; Perandones et al., 1993).

The present study showed the protective role of the tested mixtures (nutraceuticals) by inhibiting the genotoxicity induced by adjuvant arthritis and the protection of cells against oxidative DNA damage. Rauscher et al. (1998) reported that carotenoids, lycopene and canthaxanthin reduced the induction of micronuclei in polychromatic erythrocytes in mice bone-marrow cells by $25-46 \%$.

Several works have measured the protective effects of nut oil (hazelnut and walnut oils) against free radical capacity. Tocopherols were the active components which appear to be responsible for this antioxidant capacity. It has been cited that the combination of tocopherol with other micronutrients provided protective effects against argemone oil and sanguinarine induced genotoxicity in mice bone-marrow cells (comet assay) (Ansari et al., 2006; Arranz et al., 2008).

In the present research the mutagenic effect and DNA fragmentation in adjuvant arthritis was minimized by the oral administration of the different plant extracts which significantly inhibited the percentage of abnormality of somatic and germ cells.

The antimutagenic activity of green tea extract was previously confirmed by different methods; an in vitro gastrointestinal model with Salmonella typhimurium by Ames test (Krul et al., 2001) and in Jurkat $T$ cells against hydrogen peroxide by comet assay (Riso et al., 2002). Geetha et al. (2004) reported that green tea has antioxidant, antitumor and antimutagenic activites that are assumed to be due to high concentrations of polyphenolic content. The contents of total phenols, flavonoids and anthocyanins have been reported to be positively correlated with anti-mutagenic effects (Huang et al., 2007). Also, Tsai et al. (2007) reported that green tea and rosemary have a nitric oxide suppression activity implicated in the pathogenesis of inflammatory diseases.

\section{CONCLUSION}

Arthritic control rats compared to normal control rats showed high oxidative stress and inflammatory biomarkers and reduced colonic Bifidobacteria. The administration of different test mixtures or Bifidobacterium bifidum in arthritic rats produced a reduction in oxidative stress and inflammation. Arthritic rats given mixtures 1, 3 or Bifidobacterium bifidum showed a significant increase in colonic Bifidobacteria. Reductions in all nutritional parameters 
was noticed in the control arthritic rats compared to the normal control. All the studied mixtures and Bifidobacterium bifidum improved nutritional parameters compared to the arthritic control. Mixture 1 was superior in this respect. The results demonstrated DNA fragmentation, apoptosis and genotoxic effects on adjuvant arthritis in rats, which was significantly protected by supplementation of the mixtures. The bioactivity of mixtures could be attributed to the presence of tocopherols, carotenoids and phenolic compounds.

\section{REFERENCES}

Allen JW, Liang JC, Carrano AV, Preston JR. 1986. Review of literature on chemical-induced aneuploidy in mammalian male germ cells. Mutat Res. 167, 123137.

Amaral JS, Casal S, Torres D, Seabra RM, Oliveira BP. 2005. Simultaneous determination of tocopherols and tocotrienols in hazelnuts by a normal phase liquid chromatographic method. Analytical Sciences 21, 1545-1548.

Ansari KM, Dhawan A, Khanna SK, Das M. 2006. Protective effect of bioantioxidants on argemone oil/ sanguinarine alkaloid induced genotoxicity in mice. Cancer Letters 244, 109-118.

Arranz S, Cert R, Perez-Jimenez J, Cert A, SauraCalixto F. 2008. Comparison between free radical scavenging capacity and oxidative stability of nut oils. Food Chemistry 110, 985-990.

Bistrian BR, Blackburn GL. 1983. Assessment of proteincalorie malnutrition in the hospitalized patient. In: Nutritional Support of Medical Practice. (eds. H.A. Schneider, C.E. Anderson, D.B. Coursin) Harper and Row, New York, pp 128-153.

Blanchette L, Roy D, Belanger G, Gauthier SF. 1996. Production of cottage cheese using dressing fermented by Bifidobacteria. J. Dairy Sci. 79, 8-15.

Briggs GM, Williams MA. 1963. A new mineral mixture for experimental rat diets and evaluation of other mineral mixtures. Fed. Proc. 22, 261-266.

Burton K. 1956. A study of the conditions and mechanism of the diphenylamine reaction for the colorimetric estimation of deoxyribonucleic acid. Bichem. J. 62 , 315-323.

Daddaoua A, Martinez-plata E, Lòpez-Posadas R, Vieites JM, González M, Requena P, Zarzuelo A, Suárez MD, de Medina FS, Martinez-Augustin $O$. 2007. Active hexose correlated compound acts as a prebiotic and is anti-inflammatory in rats with hapteninduced colitis. J. Nutr. 137, 1222-8.

de Grauw JC, van de Lest CH, van Weeren PR. 2009. Inflammatory mediators and cartilage biomarkers in synovial fluid after a single inflammatory insult: a longitudinal experimental study. Arthritis Res. Ther. 11, R35.

Dietrich M, Traber MG, Jacques PF, Cross CE, Hu Y, Block G. 2006. Does gamma-tocopherol play a role in the primary prevention of heart disease and cancer? A review. J. Am. Coll. Nutr. 25, 292-9.

Evans EP, Breckon G, Ford CE. 1964. An air-drying method for meiotic preparations for mammalian testes. Cytogenetics 3, 289-294.

Fagan JM, Waxman L, Goldberg AL. 1987. Skeletal muscle and liver contain a soluble ATP + ubiqutin-dependent protedytic system. Biochem. J. 243, 335-340.
Frizen BN. 1994. Rheumatoid arthritis and the intestinal microbiocenosis. Ter. Arkh. 66, 17-21.

Garg ML, Blake RJ, Wills RB, Clayton EH (2007) Macadamia Nut Consumption Modulates Favourably Risk Factors for Coronary Artery Disease in Hypercholesterolemic Subjects. Lipids 42, 583-7.

Geetha T, Garg A, Chopra K, Kaur IP. 2004. Delineation of antimutagenic activity of catechin, epicatechin and green tea extract. Mutation Research/ Fundamental and Molecular Mechanisms of Mutagenesis 556, 65-74.

Glenn EM, Kooyers WM. 1966. Plasma inflammation units: An objective method for investigating effects of drugs on experimental inflammation. Life Sci. 5, 619-628.

Goodman AG, Goodman LS, Gilman A. 1980. Principles of toxicology, In: The Pharmacological Basis of Therapeutics, (eds. Goodman and Gilman). $6^{\text {th }}$ ed. Macmillan, New York, p.1602-1615.

Granado M, Priego T, Martín AI, Villanuá MA., LòpezCalderòn A. 2005. Ghrelin receptor agonist GHRP-2 prevents arthritis-induced increase in E3 ubiquitin-ligating enzymes MuRF1 and MAFbx gene expression in skeletal muscle. American Journal of Physiology, Endocrinology and Metabolism 289, E1007-E1014.

Halliwell B. 2002. Effect of diet on cancer development: is oxidative DNA damage a biomarker? Free Radical Biology and Medicine 32, 968-974.

Huang YC, Chang YH, Shao YY. 2006. Effects of genotype and treatment on the antioxidant activity of sweet potato in Taiwan. Food Chemistry 98, 529-538.

Ialinti A, Moncada S, Dirosa M. 1993 Modulation of adjuvant arthritis by endogenous nitric oxide. $\mathrm{Br}$. J. Pharmacol. 110, 701-706.

Ibáñez de Cáceres I, Villanúa M, Soto L, Martín Al, López-Calderón A. 2000. Insulin like growth factor (IGF-I) and IGF-binding proteins in rats with adjuvantinduced arthritis given recombinant human growth hormone. J. Endocrinol. 165, 537-544.

Kim SW, Kim HM, Yang KM, Kim SA, An MJ, Park JJ, Le Sk, Kim TI, Kim Wh, Cheon JH. 2010. Bifidobacterium lactis inhibits NF-KappaB in intestinal epithelial cells and prevents acute colitis-associated colon cancer in mice. Inflamm Bowel Dis. (Epub ahead of print) PMID: 20310012.

Kim TJ, Silva JL, Jung YS. 2009. Antibacterial activity of fresh and processed red muscadine juice and the role of their polar compounds on Escherichia coli 0157:H7. J. Appl. Microbiol. 107, 533-9.

Kinne RW, Lier T, Beensen V, Kunisch E, Zimmermann $\mathrm{T}$, Holland H, Pfeiffer R, Stahl HD, Lungershausen W, Hein G, Roth A, Emmrich F, Claussen U, Froster UG. 2001. Mosaic chromosomal aberrations in synovial fibroblasts of patients with rheumatoid arthritis, osteoarthritis, and other inflammatory joint diseases. Arthritis Res. 3, 319-330.

Kluth D, Banning A, Paur I, Blomhoff R, Brigelius-Flohe R. 2007. Modulation of pregnane $X$ receptor- and electrophile responsive element-mediated gene expression by dietary polyphenolic compounds. Free Radic. Biol. Med. 42, 315-25.

Koracevic D, Koracevic G, Djordjevic V, Anderejevic S, Cosic V. 2001. Methods for the measurement of antioxidant activity in human fluids. J. Clin. Pathol. 54, 356-361. 
Krul C, Luiten-Schuite A, Tenfelde A, Ommen BV, Verhagen H, Havenaar R. 2001. Antimutagenic activity of green tea and black tea extracts studied in a dynamic in vitro gastrointestinal model. Mutat Res Fundamental and Molecular Mechanisms of Mutagenesis 474, 71-85.

Lecker SH, JagoeRT, Gilbert A,GomesM,BaracosV, Bailey J, Price SR, Mitch WE, Goldberg AL. 2004. Multiple types of skeletalmuscle atrophy involve a common program of changes in gene expression. FASEB Journal 18, 39-51.

Mahajan SG, Mali RG, Mehta AA. 2007. Protective Effect of Ethanolic Extract of Seeds of Moringa oleifera Lam. against Inflammation Associated with Development of Arthritis in Rats. J. Immunotoxicol 4, 39-47.

Malin M, Verronen P, Korhonen H. 1997. Dietary therapy with Lactobacillus GG, bovin colostrums or bovine immune colostrum in patients with juvenile chronic arthritis: mallet evaluation of effect of gut defense mechanisms. Inflammo. Pharmacology 5, 219-236.

Marteau P, de Vrese M, Cellier C.J, Schrezenmeir J. 2001. Protection from gastrointestinal diseases with use of probiotics. Am. J. Clin. Nutr. 73, 430S-436S.

Mennen LI, Walker R, Bennetau-Pelissero C, Scalbert A. 2005. Risks and safety of polyphenol consumption. Am. J. Clin. Nutr. 81, 326S-329S.

Misra AK, Kuila RK. 1992. Use of Bifidobacterium bifidum in the manufacture of bifidus milk and its antibacterial activity. Lait 72, 213-220.

Morcos SR. 1967. The effect of protein value of the diet on the neurological manifestations produced in rats by $\beta, \beta$-immodipropionitrile. Br. J. Nutr. 21, 269-274.

Mythilypriya R, Shanthi P, Sachdanandam P. 2008. Salubrious effect of Kalpaamruthaa, a modified indigenous preparation in adjuvant- induced arthritis in rats-A biochemical approach. Chemico-Biological Interactions 173, 148-158.

Paget P, Barnes T. 1964. Evaluation of drug activities Pharmacometrics, Vol. (1), (eds. D. R. Laurrence, A.L. Bacharach). Academic Press, London and New York, p.135-140.

Perandones CE, Illera VA, Peckham D, Stunz LL, Ashman R. 1993. Regulation of apoptosis in vitro in mature murine spleen T cells. J. of Immunology 151, 3521-3529.

Pishak OV. 1999. The colonization resistance of the mucous membrane of the large intestine in patients with rheumatoid arthritis in a period of exacerbation. Microbiol. Z. 61, 41-7

Pleban AP, Munyani A, Beachum J. 1982. Determinationof selenium concentration and glutathione peroxidase activity in plasma and erythrocytes. Clin. Chem. 28, 311-316.

Prakash D, Singh BN, Upadhyay G. 2007. Antioxidant and free radical scavenging activities of phenols from onion (Allium cepa). Food Chemistry 102, 1389-1393.

Rapp M, Therman E, Deniston C. 1977. Non-pairing of the $X$ and $Y$ chromosomes in the spermatocytes of BDF1 mice. Cytogenet Cell Genet 19, 85-93.

Ratnam VD, Ankola DD, Bhardwaj V, Sahana DK, Ravi Kumar MNV. 2006. Role of antioxidants in prophylaxis and therapy: A pharmaceutical perspective. Journal of Controlled Release 113, 189-207.
Rauscher R, Edenharder R, Platt KL. 1998. In vitro antimutagenic and in vivo anticlastogenic effect of caroteniods and solvent extracts from fruits and vegetables rich in carotenoids. Mutat. Res. Genetic Toxicology and Environmental Mutagenesis 413, 129-142.

Riso P, Erba D, Criscuoli F, Testolin G. 2002. Effect of green tea extract on DNA repair and oxidative damage due to $\mathrm{H} 2 \mathrm{O} 2$ in Jurkat $\mathrm{T}$ cells. Nutition Research 22, 1143-1150.

Roth EF, Gilgert HS. 1984. The pyrogallol assay for superoxide dismutase: absence of glutathione artifact. Anal. Biochem. 137, 50-53.

Satoh K. 1978. Serum lipid peroxide in cerebrovascular disorders determined by a new colorimetric method. Clinica Chimica Acta 20, 37-43.

Simpson KL, Tsou CS, Chichester CO. 1985. Carotenes. In: Augustin J, Klein BP, Becker D, PB Venugopal: Methods of vitamin assay. 4th edn. John Wiley and Sons, New York, pp 185.

Singleton VL, Rossi JA. 1965. Colorimetry of total phenolics with phosphomolybdic-phosphotungstic acid reagents. Am. J. Enol. Vitic. 16, 144-158.

Singh GB, Singh S, Bani S, Gupta BD, Banerje SK. 1992. Anti-inflammatory activity of oleanolic acid in rats and mice. J. Pharm. Pharmacol 44, 456-8.

Stepaniak JA, Gould KE, Sun D, Swanborg RH. 1995. A comparative study of experimental autoimmune encephalomyelitis in Lewis and DA rats. J. Immunol. 155, 2762-2769.

Strosova M, Karlovska J, Spickett CM, Orszagova Z, Ponist S, Bauerova K, Mihalova D, Horakova L. 2009. Modulation of SERCA in the chronic phase of adjuvant arthritis as a possible adaptation mechanism of redox imbalance. Free Radic. Res. 43, 852-64.

Tastekin N, Aydogdu N, Dokmeci D, Usta U, Birtane M, Erbas H, Ture M. 2007. Protective effects of L-carnitine and alpha-lipoic acid in rats with adjuvant arthritis. Pharmacol Res. 56, 303-10.

Toor RK, Savage GP. 2006. Effect of semi-drying on the antioxidant components of tomatoes. Food Chem. 94, 90-97.

Tsai PJ, Tsai TH, YU CH, Ho SC. 2007. Comparison of NO-scavenging and NO-suppressing activities of different herbal teas with those of green tea. Food Chem. 103, 181-187.

Tuncer S, Kamanli A, Akcil E, Kavas GO, Seckin B, Atay MB. 1999. Trace elements and magnesium levels and superoxide dismutase activity in rheumatoid arthritis. Biol. Trace Elem. Res. 68, 137-42.

Vulevic J, Drakoularakou A, Yaqoob, Tzortzis G, Gibson GR. 2008. Modulation of the fecal microflora profile and immune function by a novel transgalactooligosaccharide mixture (B-GOS) in healthy elderly. Am. J. Clin. Nutr. 88, 1438-46.

Westergren A. 1921. Studies of the suspension stability of the blood in pulmonary tuberculosis. Acta Medica Scandinavica 54, 247-249.

Yosida TH, Amano K. 1965. Autosomal polymorphism in laboratory bred and wild Norway rat, Rattus norvegicus. Misima Chromosoma 16, 658-667.

Wyllie A, Kerr H, Currie AR. 1980. Cell death the significance of apoptosis. Int. Rev. Cytol. 68, 251-306.

Recibido: $24 / 8 / 10$ Aceptado: 22/12/10 